 \\ The purpose and benefit's of a product demonstration
}

\section{A.S. KSHIRSAGAR}

Received : 25.06.2018; Revised : 08.09.2018; Accepted : 18.09 .2018

\begin{abstract}
The study aimed at promotional strategies of Poorva Chemtech Pvt. Ltd. the study was conducted in and around villages of Nasik district. All the villages are located in area of Nasik city, Maharashtra state. It has been observed that more number of agriculture input industries are present in Nasik district of Maharashtra (38 numbers). From this district, Poorva Chemtech is selected on the basis of large production of Agro Chemicals. Various advertising and promotional mediums are used by Poorva Chemtech for sales of different products. This paper mainly highlights the task of demonstration of Agro Chemicals in nearby villages of Nasik district and Under this assignment survey was conducted in Villages where demonstration plays important role in sales, to find out in which area sale is less of agro-chemicals of Poorva Chem-tech, Marketing department employees of Poorva Chemtech guided to select the area in which demonstration should be done and after completion of the activity we found out the impact on customer along with the impact it has happened on sales in that area. Mostly impact of free samples promotion is positive (Bawa and Shoemaker, 2004). The effects of free sample promotions on incremental brand sales.
\end{abstract}

KEY WORDS : Advertisement, Demonstration, Agro-chemicals, Promotion

How to cite this paper : Kshirsagar, A.S. (2018). The purpose and benefit's of a product demonstration. Internat. J. Com. \& Bus. Manage, 11(2) : 132-136, DOI: 10.15740/HAS/IJCBM/11.2/132-136. Copyright@ 2018: Hind Agri-Horticultural Society.

\section{AUTHOR FOR CORRESPONDENCE}

A.S. Kshirsagar, College of Agriculture Business Management, Loni, Ahmednagar (M.S.) India

E-mail: kshirsagarashish9730@gmail.com 